\title{
PENERAPAN PRINSIP-PRINSIP TEORI BLUE OCEAN STRATEGY PADA DAKWAH NABI MUHAMMAD SAW.
}

\author{
Ahmad Nofal Abudi \& Stefanie Dana Victory \\ STID Al-Hadid, Surabaya \\ nofalabudi88@gmail.com \& stefanidv1@gmail.com
}

\begin{abstract}
Abstrak: Organisasi dakwah terkadang berhadapan dengan situasi persaingan yang ketat, dengan pesaing dominan dan sumber daya lebih kuat, sehingga peluang untuk memenangi segmen dakwah menjadi sulit (red ocean). Pada keadaan tersebut dibutuhkan terobosan strategi sebagaimana teori strategi blue ocean. Keadaan serupa pernah dialami Nabi Muhammad saw. saat berdakwah di Makkah, yaitu saat paman, dan istri Nabi meninggal. Namun Nabi berhasil keluar dari kesulitan tersebut dan sukses di Madinah. Keberhasilan tersebut mengindikasikan terdapat prinsipprinsip blue ocean strategy dalam dakwah Nabi. Oleh karenanya studi ini berorientasi mengetahui penerapan prinsip-prinsip blue ocean strategy pada dakwah Nabi, khususnya dalam peristiwa hijrah ke Madinah, dan yang mengiringinya. Metodologi studi adalah kualitatif pustaka. Data dikumpulkan dari sumber-sumber kepustakaan yang relevan. Teknik analisis kualitatif dipandu operasionalisasi teori blue ocean strategy. Hasil studi menunjukkan terdapat empat prinsip blue ocean dalam dakwah Nabi: (1) pembatasan pasar dengan inovasi produk dakwah namun tidak mengubah substansinya; (2) prinsip kedua dijalankan simultan dengan prinsip ketiga, melalui keunggulan kompetitif subjek dan perumusan strategi dakwah dengan mencari pasar baru di luar Makkah; (3) prinsip keempat terkait keberhasilan implementasi strategi, yang ditunjukkan dengan adanya utilitas istimewa bagi mad'uw.

Kata Kunci: Blue ocean strategy, strategi dakwah, hijrah Nabi Muhammad saw.
\end{abstract}

Applying Principles of Blue Ocean Strategy Theory on The Prophet Muhammad's Da'wah. Abstract: Da'wah organization sometimes deals with firm competition (red ocean) among a strong and dominant competitors that the chance to win da'wah segment is closely hard. In red ocean, a strategic breakthrough is needed as the blue ocean strategy theory. Those circumstances was experienced by the Prophet Muhammad (PBUH) while he was propagating in Mecca after the demises of the Prophet's uncle and wife. However, he overcome the situation and succeeded in Medina. This indicates there are principles of the blue ocean strategy applied in Prophet's Da'wah. Therefore, this study aims to discover the application of blue ocean strategy principles on the Prophet's Da'wah, especially on Hijrah and which accompanies it. It uses qualitative literature methods, data based on relevant literature sources. The qualitative analysis are guided by the operation of blue ocean strategy theory. It results there are four of blue oceans principles on Prophet's Da'wah: (1) reconstructing market boundaries, by innovating da'wah product without changing its core value; (2) the second principles works simultaneously with the third principles, through the subject's competitive advantage and the formulation of da'wah strategy by creating a new market outside Mecca (3) fourth, the availability of exceptional product utility for mad'uw as the successful strategy implementation. 
Keywords: blue ocean strategy, da'wah strategy, the Hijrah of Prophet's Muhammad

\section{Pendahuluan}

Aktivitas dakwah yang dilaksanakan dengan prinsip-prinsip manajemen akan lebih menjamin dakwah tersebut bisa mencapai tujuan yang ditetapkan oleh lembaga dakwah dengan melakukan pengorbanan yang sewajarnya dilakukannya. ${ }^{1}$ Secara umum tujuan dakwah adalah mengajak umat manusia untuk menjalankan nilai-nilai agama Islam yang diridai Allah SWT. ${ }^{2}$ Bagaimana seorang pendakwah mampu untuk membuat mad'uw sepakat hingga sampai menerapkan nilai-nilai Islam yang diberikan. Dalam proses dakwah, para subjek dakwah akan bersaing dengan penyebar pemahaman lain, baik yang sifatnya umum maupun pemahaman Islam yang lain, yang saling bersaing dalam memperebutkan kepercayaan objek dakwah. Maka menjadi penting memilih strategi terbaik yang dirasa mampu mengantarkan pada tujuan dakwah.

Mengingat begitu pentingnya strategi dalam mewujudkan tujuan dakwah, maka strategi juga harus terpikirkan dengan matang. Proses dakwah sebenarnya mirip dengan proses pemasaran (bisnis). Kesamaan tersebut bisa dilihat dari adanya subjek yang meyakinkan pasar (mad'uw) untuk membeli produk, atau jika dalam dakwah, produk dakwah bisa berupa pemikiran, kegiatan, ataupun organisasi dakwah. Selain itu, baik dalam dakwah maupun pemasaran juga

\footnotetext{
1 M.Munir dan Wahyu Ilaihi, Manajemen Dakwah (Jakarta: Rahmat semesta, 2009), 36.

2 Ibid., 88.
}

terdapat pesaing yang juga berkepentingan untuk memperoleh pembelian dari pasar. Pesaing dalam proses dakwah adalah semua pihak yang berupaya memengaruhi pasar yang sedang diproses oleh subjek dakwah untuk membatalkan atau mengurangi proses pembelian dari pasar (baik organisasi dakwah lain atau kegiatan lain, ataupun orang di sekeliling pasar). Proses pembelian pasar dalam dakwah adalah berupa dipercayainya atau diikutinya pemikiran, kegiatan ataupun organisasi dakwah. Dengan adanya kesamaan-kesamaan tersebut maka strategi yang bisa diterapkan dalam proses pemasaran juga bisa diterapkan dalam bidang dakwah. Salah satu strategi yang cukup populer dalam pemasaran adalah blue ocean strategy. Dengan adanya kesamaan-kesamaan antara dakwah dan pemasaran, maka blue ocean strategy secara logika juga memiliki kesesuaian dengan bidang dakwah.

Makna blue ocean atau samudra biru adalah semua industri yang belum diciptakan, dimana laba dan pertumbuhan lebih banyak terjadi. ${ }^{3}$ Blue ocean strategy memiliki khasnya tersendiri, latar belakang dari teori strategi ini adalah adanya situasi red ocean. Red ocean adalah semua industri yang datang sekarang tempat sebagian besar organisasi untuk bertarung. ${ }^{4}$ Adanya banyak kompetitor yang bertarung pada lingkup yang sama dimana untuk memenangkan kompetisi tersebut harus bertarung mati-

\footnotetext{
${ }^{3}$ W. Chan Kim dan Renee Mauborgne, Blue Ocean Shift Pergeseran Samudra Biru Melampaui Persaingan (Jakarta:PT Gramedia Pustaka Utama, 2017), 17 ${ }^{4}$ Ibid., 5
} 
matian. Sumber daya yang dimiliki juga akan banyak terkuras untuk memenangkan kompetisi yang sengit dengan kompetitor. Karena adanya latar belakang tersebut (red ocean), muncullah sebuah solusi yang baru. Oleh karena itu muncullah strategi blue ocean yang direkomendasikan menghadapi kondisi red ocean. Hal tersebut terjadi karena sumber daya yang dimiliki juga kecil secara kuantitas maupun kualitas, lawan memiliki kemampuan internal yang jauh lebih tinggi, dan cenderung lebih superior. Oleh karenanya persaingan akan menjadi red ocean, sebuah persaingan yang berdarah-darah ketika bertempur di sana. Maka yang harus di lakukan adalah bersaing di luar apa yang sedang dipersaingkan oleh kompetitor. Di bidang dakwah juga ada kesesuaian dengan asumsi tersebut, terutama pada substansi latar belakang adanya teori blue ocean strategy yaitu adanya persaingan yang amat ketat dan pesaing yang superior. Pesaing ini bisa berupa pesaing langsung yang memengaruhi kemauan mad'uw untuk membeli produk subjek dakwah (organisasi dakwah) yang menawarkan pemikiran dalam aspek yang sama tetapi berbeda arah, atau organisasi dakwah dan organisasi lain yang menawarkan kegiatan secara bersamaan dengan kegiatan dakwah, dan lain-lain. Terkadang seorang subjek dakwah mendapati pesaing yang sangat kuat/superior, seperti yang dialami Nabi Muhammad saw. di Mekah yang menghadapi tokoh-tokoh Suku Quraisy yang memiliki keyakinan paganisme, sedangkan Nabi Muhammad saw. menyebarkan keyakinan tauhid dalam Islam. Maka dengan demikian blue ocean strategy juga memiliki kesesuaian secara asumsi dengan bidang dakwah.
Blue ocean strategy menjadi suatu hal yang menarik untuk dikaji, karena strategi ini mengajarkan untuk selalu mencari celah yang ada di pasar yang bisa dimanfaatkan. Sehingga mengetahui dimana letak perbaikan pada organisasi yang dijalankan, hal apa yang perlu ditingkatkan, dikurangi, dihapuskan, atau diciptakan. Dengan begitu akan menemukan celah untuk membuka pasar dan bersaing lebih ringan di sana, dan peluang kemenangan akan semakin besar. Ciri khas dari strategi blue ocean adalah bagaimana mampu menciptakan inovasi produk baru yang berpijak pada kebutuhan pasar yang tidak dilihat oleh kompetitor, sehingga nantinya akan menghasilkan pasar dengan segmen yang baru juga.

Ketika teori blue ocean strategy ini diterapkan di dalam konteks dakwah maka akan menjadi suatu hal yang menarik, mengingat masih jarang sekali organisasi dakwah menggunakan blue ocean strategy. Kebanyakan organisasi dakwah yang ada sibuk memenangkan kompetisi dengan medan yang berdarah-darah, secara biaya yang dikeluarkan besar untuk memenangkan kompetisi, terlebih apabila pesaingnya dominan. Jika yang menjadi aktor adalah organisasi yang besar, mungkin bisa jadi mereka siap untuk berkompetisi melawan kompetitornya di medan yang berdarahdarah ketika memang sumber daya yang dimiliki cukup untuk memenangkan pertarungan. Namun bagaimana dengan organisasi yang masih kecil yang memang secara kapasitas tidak sanggup untuk memenangkan pertarungan melawan kompetitor yang secara skala sudah jauh lebih besar modalnya. Atau organisasi besar yang masih kalah dengan kompetitornya dan sudah berdarah-darah di red ocean justru akan terancam tidak sukses dakwahnya. 
Oleh karena itu strategi blue ocean bisa menjadi alternatif strategi untuk menyukseskan dakwah.

Penerapan strategi blue ocean akan menjadi terobosan baru dalam memasarkan dakwah dengan cara yang mungkin di luar kebiasaan dalam merencanakan pemasaran dakwah. Blue ocean secara titik tekan adalah bagaimana mencari celah pasar baru yang tidak pernah dibidik oleh kompetitor sebelumnya. Sehingga dari situ dapat menemukan inovasi produk untuk ditawarkan ke pasar yang lebih spesifik, sehingga melahirkan ceruk pasar baru dengan kebutuhan dan keinginan yang berbeda. Dengan begitu untuk organisasi dakwah yang secara sumber daya masih minimal, tidak harus berhadapan langsung dengan kompetitor dan bersaing dengan produk dakwah yang sama dan berkompetisi secara berdarah-darah. Melainkan bisa menciptakan inovasi produk yang ini tidak pernah dipenuhi oleh lawan, sehingga organisasi bisa survive. Ini adalah langkah strategis yang sekiranya tidak hanya bisa diterapkan pada organisasi dakwah yang baru saja, namun prinsipnya organisasi dakwah yang tidak bisa atau tidak mampu jika melawan kompetitor yang superior.

Jika berbicara dakwah, maka identik dengan tokoh Islam yaitu Nabi Muhammad saw. karena beliaulah yang menjadi panutan umat muslim dalam menyebarkan agama Islam sebagai agama yang rahmatan lil alamin. Nabi juga menjadi pendakwah agama Islam pertama kali dan mampu menyukseskan dakwahnya. Melihat perjuangan Nabi dalam dakwahnya mulai dari masa saat di Makkah hingga ke Madinah mengalami banyak sekali dinamika perubahan. Nabi berdakwah di Makkah selama tiga belas tahun, namun secara perkembangan Islam masih belum pesat. Dakwah Nabi baru berkembang pesat manakala di Madinah, dalam waktu sepuluh tahun pengikut Islam menjadi besar dan banyak. Bahkan Islam yang awalnya menjadi agama yang minoritas menjadi agama yang mayoritas, kuat dan besar di Arab. Konteks ini menjadi menarik untuk digali mengingat ada perbedaan pasar dan perkembangan dakwah Islam yang sangat signifikan. Bahkan tidak perlu waktu yang lama seperti di Makkah dakwah Nabi begitu cepat dan lebih mudah diterima di Madinah.

Terdapat beberapa hal yang membuat dakwah Nabi di Makkah banyak hambatan. Jika dilihat peta lingkungannya, suku yang menguasai Makkah adalah Quraisy. Semua jabatan-jabatan strategis dalam organisasi kesukuan di Makkah di duduki oleh Quraisy. Agama yang dianut didasarkan pada tradisi nenek moyang, yaitu penyembahan berhala. Nabi sendiri berasal dari salah satu marga Quraisy, yaitu Bani Hasyim, yang juga dihormati di Makkah. Paman Nabi, Abu Thalib bin Abdul Muthallib adalah pimpinan Bani Hasyim, sangat dihormati, dan menjadi pelindung Nabi selama dakwahnya di Makkah. Namun kekuatan tersebut tidak berlangsung lama, karena kemudian paman Nabi meninggal, sehingga menjadi ancaman baru karena berarti tidak ada yang melindungi Nabi lagi. Suku Quraisy sendiri tidak mau kekuasaannnya dihancurkan oleh agama Islam, harga diri yang tinggi, menjadikan mereka tidak mau mengakui bahwa ajaran yang dibawa Nabi Muhammad adalah kebenaran. Hal tersebut mendorong mereka untuk melakukan tekanan terhadap Nabi dan pengikutnya berupa fitnah hingga embargo ekonomi. Tekanan ini semakin meningkat hingga mengarah ke penyiksaan 
fisik dan pembunuhan pada saat pasca Paman Nabi dan Istri Nabi (Khadijah) wafat (tahun duka cita).

Melihat keadaan Nabi yang demikian, maka terdapat kesesuaian dengan kekhasan keadaan strategi blue ocean. Indikasinya kompetitor memiliki kapasitas yang besar, baik secara pengaruh maupun secara jumlah pengikutnya. Suku Quraisy yang menentang dakwah Nabi Muhammad adalah kompetitor superior yang juga menawarkan produk gagasan paganisme di masyarakat, dan melawan secara keras setiap upaya dakwah Nabi di masyarakat Makkah. Nabi akhirnya berhasil keluar dari situasi persaingan yang keras dan berdarah-darah tersebut, dengan mengembangkan pasar baru dan hijrah ke Madinah. Oleh karenanya studi ini akan mendalami penerapan prinsip-prinsip blue ocean strategy dalam konteks dakwah $\mathrm{Nabi}$ Muhammad saw.

Studi ini memiliki orientasi mengetahui atau mendeskripsikan penerapan prinsip-prinsip blue ocean strategy pada dakwah Nabi Muhammad saw. pada periode setelah tahun duka cita (tahun $620 \mathrm{M}$ atau tahun kesepuluh kenabian) hingga Hijrah ke Madinah. Harapannya studi ini dapat bermanfaat menjadi referensi untuk pengembangan strategi dakwah yang berkemungkinan memiliki konteks yang sama (red ocean) dengan Nabi Muhammad saw. Ruang lingkup studi mencakup konteks hijrah Nabi Muhammad saw. yang dimulai dari beliau melakukan dakwah ke berbagai kabilah yang di luar Makkah pasca paman

\footnotetext{
${ }^{5}$ Lexy J. Moleong, Metodologi Penelitian Kualitatif, Cetakan ketigapuluhempat, (Bandung: Rosda, 2015), 6.

6 Mestika Zed, Metode Penelitian Kepustakaan (Jakarta: Yayasan Obor Indonesia, 2004), 1.
}

dan istri beliau meninggal dunia, hingga Nabi hijrah ke Madinah untuk pertama kali, dan respon masyarakat Yastrib (Madinah) saat melihat hijrahnya Nabi.

Metodologi studi ini adalah kualitatif pustaka. Kualitatif karena tujuannya hendak mengetahui sebuah peristiwa secara utuh terkait subjek studi, ${ }^{5}$ yaitu dakwah Nabi Muhammad pada periode tertentu, dalam kerangka penerapan teori strategi blue ocean. Strategi kepustakaan digunakan mengingat subjek, situasi sosial, dan aktivitas yang dikaji adalah peristiwa sejarah, yaitu sejarah dakwah Nabi. Sehingga perlu menggali data-data terkait berdasarkan sumber pustaka yang relevan. ${ }^{6}$ Adapun pustaka sejarah utama yang digunakan, adalah: (a) Sirah Nabawiyah karya Ibnu Ishaq \& Ibnu Hisyam; (b) Sejarah Hidup Muhammad karya M. Husain Haekal; (c) Sirah Nabawiyah karya Al-Mubarakfuri. Tiga sumber tersebut adalah sumber populer terkait sejarah dakwah Nabi. Sumber pertama mewakili karya klasik sejarah Nabi. Sumber kedua dan ketiga adalah karya modern serjarah Nabi, yang secara kredibilitas diakui. Pengumpulan data melalui pembacaan cermat dan kritis pada bagian-bagian terkait, $^{7}$ serta membandingkan satu sama lain. Teknik analisis kualitatif digunakan merujuk model Miles dan Huberman, dalam tiga langkah yang dilakukan secara interaktif, yaitu reduksi data, penyajian data, dan penarikan kesimpulan. $^{8}$

\footnotetext{
7 lbid., 31.

8 Matthew B. Miles dan A. Michael Huberman, Analisis Data Kualitatif, diterjemahkan oleh Tjejep Rohendi Rohidi, (Jakata: UI Press, 1992), 15-16.
} 


\section{Konsep Dakwah}

Dakwah Islam menurut M. Munir dan Wahyu Ilaihi dalam bukunya manajemen dakwah, adalah kegiatan mengajak, mendorong dan memotivasi orang lain berdasarkan bashirah untuk meniti jalan Allah dan istiqomah di jalan-Nya serta berjuang bersama meninggikan agama Allah. ${ }^{9}$ Adapun unsurunsur dari dakwah sebagai berikut: (a) dai, adalah orang yang melaksanakan dakwah baik secara lisan, tulisan, maupun perbuatan yang seusai dengan ajaran Islam, yang dilakukan secara invidu, kelompok, atau melalui organisasi atau lembaga; ${ }^{10}$ (b) mad'uw, adalah orang yang menjadi sasaran dakwah atau orang yang nantinya ingin kita ajak untuk ikut ke ajaran Islam atau orang yang mendapatkan dan menerima dakwah kita, baik secara individu, kelompok atau lembaga yang beragama Islam atau yang bukan beragama Islam; ${ }^{11}$ (c) maddah, adalah isi pesan yang nantinya akan disampaikan kepada mad'uw; $^{12}$ (d) wasilah, adalah media yang digunakan untuk menyampaikan pesan dakwah kepada mad'uw; ${ }^{13}$ (e) thariqah atau metode dakwah adalah cara/strategi dakwah yang digunakan oleh dai untuk menyampaikan ajaran Islam. Hal ini bisa menjadi cara yang akan digunakan untuk mencapai sebuah tujuan yang berisikan rencana sistem, tata pikir manusia; ${ }^{14}$ (f) atsar atau efek adalah bentuk renpon atau feed back yang diberikan oleh mad'uw setelah mendapatkan materi dakwah dari dai. ${ }^{15}$

Seorang pendakwah atau manajer dakwah harus mampu menganalisis keadaan masyarakat, baru kemudian menentukan

\footnotetext{
${ }^{9}$ Munir dan Ilaihi, Manajemen Dakwah., 18.

$10 \mathrm{lbid}$., 21

11 lbid., 23.

12 Ibid., 24
}

apa yang harus dilakukan. Dalam hal ini ada beberapa sarana manajemen dakwah yang menentukan bagi kesuksesan pengaturan aktivitas dakwah antara lain ketersediaan informasi, komunikasi antara bawahan dan atasan yang lancar, adanya insentif yang bisa memotivasi para aktivis dakwah, saling percaya antara dai dan mad'uw, pengetahuan akan potensi yang dimiliki para dai, serta kejelasan keahlian dan otoritasnya. Salah satu yang menjadi sumber terpenting dalam mencapai tujuan adalah bagaimana merumuskan strategi. Strategi ini yang menentukan bagaimana organisasi dakwah akan bergerak ke depan untuk mencapai tujuan. Salah satu yang menjadi terpenting dirumuskan adalah rencana dakwah, karena ini yang akan menentukan bagaimana membuat produk dakwah dan memasarkan produk tersebut.

\section{Teori Blue Ocean Strategy}

Strategi blue ocean adalah strategi yang menantang perusahaan untuk keluar dari samudra merah persaingan berdarah dengan cara menciptakan ruang pasar yang belum ada pesaingnya, sehingga kata kompetisi menjadi tidak relevan. ${ }^{16}$ Dalam hal ini yang dimaksudkan adalah bagaimana suatu organisasi mampu keluar dari persaingan, dengan melihat celah yang ada di pasar, sehingga menemukan peluang di pasar dan memberikan inovasi nilai yang baru yang dimana ini tidak disasar oleh kompetitor pada medan pertarungan sebelumnya. Dengan adanya peluang seperti itu, hal ini dapat menjadi peluang tersendiri untuk mendapatkan peluang pasar baru,

\footnotetext{
13 Ibid., 32

14 Ibid., 32

15 Ibid., 34

${ }^{16}$ Kim dan Mauborgne, Blue Ocean., 10.
} 
sehingga organisasi bisa memikat hati pasar untuk membeli produknya dan dengan begitu organisasi tidak perlu bersaing di lautan merah yang memang hampir tidak mungkin menjadi pemenang dalam pertarungan itu, karena kapasitas internal organisasi yang memang tidak memadai.

Ada empat prinsip perumusan strategi blue ocean yaitu, pertama, rekonstruksi batasan pasar. Merupakan suatu upaya menciptakan samudra biru dengan membangun kembali batasan pasar pada perusahaan. Dalam strategi blue ocean, prinsip pertama yang perlu dilakukan adalah bagaimana menciptakan peluang samudra biru yang nantinya akan dimanfaatkan sebagai peluang berperang di dalamnya. Sehingga bisa mengganti pertarungan yang tadinya berasal dari samudra merah menjadi pertarungan samudra biru, dimana peluang memenangkan kompetisi dengan kompetitor lebih besar. Ketika sebuah perusahaan menciptakan samudra biru yang harus dilakukan adalah bagaimana bisa memetakan pasar yang potensial dan bisa dijangkau dari sekian banyak segmen pasar yang ada, dan secara daya tarik tinggi di pasaran, tapi hal tersebut tidak dilihat oleh kompetitor sebagai tempat pertarungan yang menguntungkan untuk diperebutkan. Dalam rangka menciptakan samudra biru, diperlukan langkah-langkah yang berpangkal dari mengeluarkan diri dari samudra merah. Agar manajer bisa keluar dari samudra merah, perlu untuk mendobrak batasan batasan umum terkait cara mereka berkompetisi. Manajer perlu mengkaji secara sistematis batasan-batasan tersebut untuk menciptakan samudra biru. Langkahlangkah dalam merekonstruksi batasan pasar adalah manajer perlu mencermati industri alternatif, kelompok strategis, kelompok pembeli, penawaran produk dan jasa pelengkap, orientasi fungsionalemosional suatu industri, dan bahkan waktu. ${ }^{17}$ Langkah-langkah tersebut akan memberikan organisasi pengetahuan mengenai rekonstruksi realitas-realitas pasar untuk mewujudkan samudra biru. Pada studi ini dibatasi hanya sampai pada prinsip-prinsip strategi blue ocean, sehingga tidak diuraikan teknis langkahnya. Operasionalisasi konsep rekonstruksi batasan pasar dalam dakwah adalah subjek dakwah berupaya membuat blue ocean (medan persaingan baru yang subjek dakwah lebih kuat posisinya dibandingkan para pesaingnya) dengan cara merekonstruksi batasan mad'uw-nya. Dalam rangka mewujudkannya, subjek dakwah perlu mencermati kembali pasar dakwahnya beserta segala kebutuhannya, terutama kebutuhan mendasarnya saat itu, sekaligus juga melihat dan menelaah produk produk yang ditawarkan pesaing kepada mad'uw terkait kebutuhan mana yang mampu dipenuhi oleh produk tersebut. Dengan demikian akan muncul inspirasi inovasi produk yang ditawarkan ke pasar sehingga menciptakan medan persaingan baru dalam samudera biru (blue ocean).

Kedua, fokus pada gambaran besar. Selanjutnya adalah bagaimana cara penerapan ide-ide yang sudah ditemukan ke perencanaan strategi yang nantinya akan dilakukan melalui kanvas strategi menuju ke samudra biru. Prinsip fokus pada gambaran besar adalah merupakan upaya merumuskan rencana strategi perusahaan yang memasukkan ide blue ocean ke

17 Ibid., 77. 
dalamnya, sehingga perusahaan mampu merealisasikan ide blue ocean-nya. Dalam hal ini teori blue ocean strategy, mengidekan fokus kepada hal-hal yang lebih kongkret untuk menggambarkan strategi. Manfaat dibuatnya kanvas strategi antara lain dapat menunjukkan profil strategis organisasi dan kompetitor serta profil nilai perusahaan. Jika sudah menemukan profil strategis, akan mudah membuat fokus, divergensi, dan moto yang memikat. Jika tidak memenuhi hal tersebut, maka akan sulit, karena strateginya tidak jelas, tidak unik dan akan sulit untuk dimengerti oleh orang yang membacanya. ${ }^{18}$ Dibuatnya profil organisasi subjek dan organisasi pesaing pada intinya hendak menemukan keunggulan kompetitif subjek terhadap pesaing, dan keunggulan ini perlu disadari dan menjadi panduan dalam implementasi strategi di lapangan. Dalam bidang dakwah operasionalisasi prinsip ini merumuskan rencana strategi organisasi dakwah yang memasukkan ide blue ocean yang telah dirumuskan pada prinsip sebelumnya.

Ketiga, menjangkau melampaui permintaan yang ada. Pada prinsip ini, blue ocean mencoba meningkatkan permintaan dengan kapasitas paling maksimal atas sebuah penawaran yang baru dan berbeda dari sebelumnya. Prinsip ini mengantisipasi hanya ditemukan pasar yang sempit (hanya kubangan biru, istilah yang dipakai W. Chan Kim dan Renee Mauborgne dalam bukunya blue ocean strategy). ${ }^{19}$ Kebanyakan dari organsiasi yang ada, mereka menginginkan mempertahankan dan memperluas pasar yang mereka target, namun pada kenyataannya banyak yang akhirnya mengarah pada segmen yang lebih kecil,

\footnotetext{
18 Ibid., 121

19 Ibid., 119.
}

karena mereka harus dihadapkan dengan persaingan yang ketat. Akhirnya yang kebanyakan mereka lakukan adalah dengan cara mendesain produknya secara kustomisasi. Hal ini justru mempersempit pasar yang mereka target, dan akan semakin kecil nilai permintaannya. Sebaliknya di dalam strategi blue ocean, justru diajak untuk berpikir berlawanan, dimana yang diperhatikan bukan hanya sekadar konsumen, bahkan nonkonsumen pun juga dicermati dan berpotensi untuk ditarget. Sehingga bukan berfokus pada perbedaan konsumen yang ada, namun juga perlu mengembangkan hal-hal yang dihargai oleh pembeli pada umumnya.

Pada penjelasan teori blue ocean strategy tidak disebutkan secara eksplisit definisi konsumen dan pembeli, tetapi ada beberapa ilustrasi dan penjelasan konsep yang bisa ditarik kesimpulan mengenai pengertian istilah konsumen. Pengertian tersebut sejalan dengan pendapat P. Kotler dan Gary Armstrong dalam bukunya Prinsip-Prinsip Pemasaran Jilid 1 bahwa pasar konsumen adalah semua individu dan rumah tangga yang membeli atau mendapatkan barang dan jasa untuk konsumsi pribadi. ${ }^{20}$ Sedangkan maksud pembeli secara umum adalah orang yang melakukan aktivitas pembelian produk, baik produk subjek ataupun produk lainnya, sehingga termasuk di luar konsumen produk perusahaan (nonkonsumen). Dalam bidang dakwah, operasionalisasi prinsip tersebut adalah subjek perlu meningkatkan kapasitas/keluasan pasar dakwah dengan melakukan inovasi produk dakwah yang berbeda dari sebelumnya dengan berbasis pada apa yang dihargai oleh pasar dakwah

20 Kotler Philip \& Gary Armstrong, Prinsip-Prinsip Pemasaran Jilid 1 (Jakarta:Erlangga, 2008), 158. 
secara umum. Hal ini membuat subjek dakwah tidak hanya fokus pada pasar dakwah yang biasa menjadi target dakwah dan mengikuti (membeli), tetapi perlu juga mencermati pasar potensial yang selama ini belum pernah menjadi target pasar dakwah ataupun membeli/mengikuti produk dakwah. Dengan demikian pandangan subjek dakwah tentang pasar tidak terbatas. Pada konteks peristiwa Hijrah Nabi, pasar dakwah secara umum adalah seluruh penduduk jazirah Arab ataupun di luarnya yang berpotensi menjadi pasar dakwah Nabi Muhammad (dengan kedudukan Makkah sebagai salah satu tempat kunjungan di musim haji dan salah satu simpul perdagangan saat itu).

Keempat, menjalankan rangkaian strategis secara benar. Setelah melakukan pemetaan, memperoleh ide, dan menentukan target pasar, maka yang harus dilakukan berikutnya adalah merumuskan langkah implementasinya dengan cara membuat rangkaian strategis dan memahaminya dengan benar untuk memastikan ide blue ocean strategy yang sudah dirumuskan bisa berjalan dengan baik. Hal yang penting di sini adalah memahami cara menilai blue ocean berdasarkan kriteria kunci dalam rangkaian tersebut. Intinya adalah subjek perlu menyinergikan setiap tahapan, dengan lebih menguji supaya bisa mendapatkan pertanggungjawaban yang jelas dan lebih sesuai dengan pasar yang menjadi target. ${ }^{21}$ Titik awalnya adalah pada utilitas istimewa untuk pembeli, subjek perlu membuat instrumen pertanyaan untuk menguji apakah produk yang ditawarkan memberikan utilitas istimewa, sehingga pasar mempunyai alasan yang unik dan menarik untuk membeli produk subjek. Langkah kedua adalah menetapkan harga strategis yang tepat. Harga tersebut mampu menarik pasar untuk membeli sehingga mereka memiliki kemampuan dan daya beli untuk membeli produk subjek. Jika produk tidak mampu dibeli oleh pasar dan tidak mampu membuat pasar tertarik untuk membeli produk, maka produk juga tidak akan booming di pasaran. Langkah ketiga, apakah subjek bisa menekan biaya produksi, namun mendapatkan laba yang tinggi sesuai target, jangan sampai biaya menjadi penghalang mendapatkan harga strategis di pasar. Juga mengurangi nilai utilitas ketika biaya tinggi menghalangi untuk menciptakan harga yang strategis. Ketika biaya yang sesuai target tersebut tidak bisa dipenuhi, maka harus menghilangkan ide itu, karena medan itu tidak akan menguntungkan. Pilihan lainnya adalah dengan melakukan inovasi pada model subjek demi memenuhi biaya yang ditargetkan. Karena hal ini memengaruhi lompatan nilai (laba) yang akan diciptakan. Kombinasi dari utilitas istimewa, pemberian harga yang strategis, dan pembiayaan yang ditargetkanlah yang nantinya akan membantu subjek untuk mencapai inovasi nilai. Langkah keempat adalah menguji apakah strategi yang sudah dibuat sudah mampu menghadapi hambatan-hambatan yang akan terjadi untuk memastikan bahwa ide yang sudah dibuat tahan uji dan siap di lapangan dengan konteksnya (pengadopsian). Prinsip dari samudra biru yang justru bertentangan dengan samudra merah ini yang nantinya akan menimbulkan hambatan-hambatan yang nantinya timbul di lapangan. ${ }^{22}$

22 Ibid., 166. 
Dalam bidang dakwah, prinsip keempat dapat dioperasionalkan oleh perlunya subjek dakwah merumuskan langkah implementasi yang strategis bagi ide samudra birunya sehingga bisa terwujud dengan baik. Hal ini dimulai dengan memastikan adanya utilitas yang istimewa dari produk dakwah subjek untuk pasar dakwahnya (mad'uw), kemudian meminimalkan bentuk pengorbanan yang diberikan mad'uw pada saat membeli/menerima dan meyakini produk dakwah, serta meminimalisir biaya material ataupun nonmaterial yang dikeluarkan oleh subjek dakwah ataupun organisasi dakwah dalam memproses, menciptakan, dan menghantarkan produk dakwahnya, serta memastikan mampu mengatasi rintangan yang menghadang.

\section{Penerapan Prinsip-Prinsip Teori Blue Ocean Strategy dalam Peristiwa Hijrah Nabi}

Studi ini menganalisis peristiwa dakwah Nabi Muhammad setelah tahun duka cita (tahun $620 \mathrm{M}$ atau tahun kesepuluh dari wahyu pertama turun) hingga Nabi Hijrah ke Madinah. Di saat itu Nabi menghadapi tekanan yang luar biasa besar dari Suku Quraisy Makkah, yang merasa tersaingi dan terancam dengan dakwah $\mathrm{Nabi}$, sehingga Nabi menghadapi situasi yang sangat sulit untuk berdakwah. Suku Quraisy melalui pemuka-pemukanya adalah kompetitor dakwah yang superior. Dakwah Nabi berada dalam situasi red ocean. Oleh karenanya subjek dakwah perlu melakukan inovasiinovasi dakwah agar bisa menciptakan keunggulan kompetitif dari pesaingnya sehingga dalam lingkungan dakwah tersebut pesaing tidak mampu mengalahkannya. Di bawah ini akan disajikan babakan waktu sejarah pada rentang tersebut (tahun $620 \mathrm{M}$ hingga Nabi hijrah ke Madinah) yang disertai dengan analisis penerapan prinsip-prinsip blue ocean strategy.

\section{Prinsip-Prinsip Blue Ocean Strategy dalam Dakwah Nabi ke Kabilah-Kabilah Luar Makkah Sebelum Hijrah}

Peristiwa penting sebelum hijrah dan sangat memengaruhi jalannya dakwah Nabi Muhammad SAW (serta juga menjadi batasan awal dalam studi) adalah meninggalnya paman dan istrinya. Pada saat itu Nabi merasa sangat terpukul, ditambah lagi perlakuan orang-orang Quraisy yang semakin keras karena orang yang melindungi Nabi telah meninggal dunia. Diceritakan bahwa tekanan paling ringan yang dialami oleh Nabi adalah dari seorang pandir Quraisy menghentikan Nabi di tengah jalan, lalu menyiramkan pasir ke kepala Nabi. Mereka bukan hanya menyiksa orang-orang Islam secara fisik namun juga secara psikologis. Setelah melakukan pemboikotan kepada orang muslim, sehingga tidak boleh melakukan perdagangan oleh siapapun dan tidak boleh melakukan interaksi dengan orang di luar muslim. Setelah orang-orang yang bermakna dalam hidup Nabi meninggal, mereka kembali melakukan penyiksaan kepada Nabi, bahkan semakin keras. Mulai dari dilempar batu, diperolok, diancam akan dibunuh, hal itu sudah menjadi suatu yang dekat dan selalu dialami oleh Nabi Muhammad saw. ${ }^{23}$

Akan tetapi Nabi tidak menyerah. Beliau pergi ke Thaif untuk berdakwah, dan

23 Muhammad Husain Haekal, Sejarah Hidup Muhammad, (Bogor: Litera AntarNusa,2006), 152. 
berharap orang-orang Bani Tsakif mau menerima Islam dan mau membela keluarganya sendiri. Namun yang terjadi justru sebaliknya, bukan hanya menolak untuk masuk Islam, mereka justru menolak kemudian menghasut orang-orang pandir agar menyoraki dan memaki Nabi. ${ }^{24}$ Tidak hanya berhenti di Thaif, Nabi juga menawarkan pada kabilah-kabilah yang sedang ziarah ke Makkah. Semua yang beliau temui, akan ditawarkan Islam kepadanya. Nabi mendatangi rumah-rumah Banu Kindah, Banu Kalb, Banu Hanifah, Banu Amir bin Sa'sa'ah, namun semuanya menolak ajakan Nabi untuk masuk Islam. ${ }^{25}$ Di samping berdakwah kepada kelompok, Nabi juga berdakwah secara personal kepada masyarakat yang bukan orang Makkah. Di antara mereka ada yang mau beriman kepada Nabi ada beberapa orang yaitu: Suwaid bin Shamit, Iyas Bin Ma'adz, Abu Dzar Al-Ghifari, Tahufail bin Umar ad-Dausy, Dhimad al-Azdy. ${ }^{26}$

Beberapa orang jalanan, orang pandir dan Quraisy berusaha menghasut ketika diketahui Nabi tetap menyampaikan risalah kepada orang-orang yang berziarah ke Kakbah. Hingga Nabi menemukan tandatanda kemenangan dari masyarakat Yastrib. Mengingat Yastrib adalah tempat yang justru sangat dekat sekali dengan Nabi. Di sanalah tempat Ayahanda Nabi dimakamkan. Di sana adalah tempat keluarganya dari Banu AnNajjar, keluarga kakeknya Abdul-Muttalib dari pihak ibu. Saat masih usia 6 tahun sering diajak ibunya ke Yastrib untuk berziarah ke makam ayahnya. ${ }^{27}$ Yastrib adalah kota dengan karakteristik berikut: ${ }^{28}$ (a) dalam

\footnotetext{
24 Ibid., 153

25 Ibid., 155

26 Shafiyyurrahman Al-Mubarakfury, Shahih Sirah Nabawiyah, (Bandung: Jabal, 2012),168
}

masyarakatnya ada perselisihan, yaitu antara Suku Aus dan Khazraj serta Yahudi. Orang-orang tersebut sering kali berselisih, hingga menyebabkan peperangan. Peperangan yang sering terjadi antara Aus dan Khazraj merupakan siasat Yahudi untuk mempertahankan eksistensinya di Yatsrib; (b) adanya pengaruh rohani, dimana kaum Yahudi dikenal sebagai ahli kitab dan penganut ajaran monoteisme. Mereka tidak sepakat dengan tetangga mereka yang merupakan kaum pagan penyembah berhala. Kepada kaum pagan mereka sering mengingatkan bahwa kelak akan ada Nabi yang akan menghabisi mereka (kaum pagan) dan mendukung orang Yahudi. ${ }^{29}$

Pada suatu malam, Nabi melewati Aqabah dan Mina. Beliau mendengar suara yang sedang berbincang-bincang dan itu adalah enam pemuda Khazraj. Mereka pernah mendengar berita tentang akan adanya seorang Nabi yang nantinya datang dari orang Yahudi di Madinah. Mereka meyakini bahwa Nabi akan memerangi kaum Khazraj seperti memerangi kaum Ad dan Iram. ${ }^{30}$ Kemudian Nabi menjelaskan mengenai Islam, dan mengajak mereka untuk memeluk Islam. Ada sebagian dari orang Khazraj yang berkata bahwa ini adalah seorang Nabi seperti yang diberitakan oleh Yahudi, dia akan membantu Yahudi untuk menghancurkan mereka (orang Aus dan Khazraj), jangan sampai orang Yahudi mengetahui, dan mereka berpikir harus menjadi orang yang beriman terlebih dahulu. Mereka berharap dengan dakwah yang dibawakan Nabi, cerita orang Yahudi itu tidak akan terjadi atau akan menghentikan

\footnotetext{
${ }^{27}$ Haekal, Sejarah Hidup., 153.

28 Ibid., 167.

29 Ibid., 168.

${ }^{30}$ Al-Mubarakfury, Shahih Sirah., 174.
} 
peperangan yang terjadi di Yastrib. Akhirnya enam orang dari Yastrib tersebutlah yang membawa risalah untuk menyebarkan agama Islam di Yastrib, dan banyak orang Yastrib menerimanya. ${ }^{31}$

Pada babakan awal sebelum hijrahnya Nabi, terdapat konteks situasi sosial Nabi dan umat Islam yang mendapat tekanan fisik dan psikis yang luar biasa dari Suku Quraisy. Hal tersebut berakibat tidak hanya perkembangan dakwah menjadi sangat lambat tetapi mengancam keselamatan jiwa umat Islam saat itu. Kondisi ini merupakan suatu keadaan red ocean dalam teori blue ocean strategy. Suatu keadaan persaingan dakwah yang amat sengit (berdarah-darah) dengan pesaing dakwah (tokoh-tokoh Suku Quraisy yang menyembah berhala) justru superior menguasai pasar dibandingkan subjek dakwah. Nabi kemudian mengambil berbagai langkah strategis dakwahnya agar tetap mampu kompetitif, bahkan memperoleh kemenangan. Terdapat beberapa penerapan prinsip blue ocean strategy dari peristiwa di atas.

Pertama, dalam keadaan tersebut Nabi Muhammad merekonstruksi batasan pasar dakwahnya. Prinsip pertama dari blue ocean strategy dalam konteks dakwah adalah subjek dakwah berupaya membuat medan persaingan baru dimana secara posisi lebih kuat dibandingkan para pesaingnya dengan cara merekonstruksi batasan mad'uw-nya.

Prinsip rekonstruksi batasan mad'uw dapat dilakukan dengan mencermati para pesaing terkait produk yang ditawarkan pada pasar dakwah, dan juga mencermati pasar dakwah terkait kebutuhan yang mendasari mereka

\footnotetext{
31 Ibid., 178.
}

tertarik produk pesaing. Dalam konteks ini, pesaing adalah semua pihak yang menawarkan produk sejenis (keyakinan yang mendasari kehidupan penganutnya/agama) kepada pasar dakwah. Pasar dakwah ini bisa penduduk (kabilah-kabilah) di kota Makkah dan bisa juga kabilah-kabilah (penduduk) di jazirah Arab, karena Nabi selama ini berdakwah kepada penduduk kota Makkah ataupun orang yang datang mengunjungi Kakbah di Kota Makkah pada bulan-bulan haji. Bila mempertimbangkan makna pasar dakwah dalam konteks tersebut, maka pesaing dakwahnya antara lain tokoh-tokoh paganisme, khususnya pemuka suku Quraisy, agama Kristen dan Yahudi. Paganisme menyembah berhala sebagai perwujudan fisik dari pengatur kosmos dan alam semesta, yang sudah diwariskan secara turun temurun. Paham ini menjadi dominan di Jazirah Arab, dikarenakan secara sosiologis mereka masih dalam kelompok kabilah-kabilah pada suatu kota atau daerah. Kabilah-kabilah di Jazirah Arab terbiasa sebagai pengembara di alam yang luas dan ganas (kering, tandus), dan memiliki kultur tidak mau diatur. Bahkan saling serang di antara para kabilah merupakan hal yang biasa di antara mereka. ${ }^{32}$ Sehingga secara kebutuhan dasar mereka membutuhkan perlindungan dari ganasnya alam dan serangan dari kabilah atau suku lain. Dalam hal ini, berhala dalam pandangan mereka bisa menjadi bentuk fisik dari pengatur kosmos dan alam semesta yang mampu melindungi mereka. Agama Kristen dan Yahudi memiliki penganut yang tidak sedikit di daerah Yaman. Kristen menawarkan keyakinan bahwa dengan konsep ketuhanan trinitasnya dan konsep kasih sayangnya akan merasakan kebahagiaan dunia dan

\footnotetext{
32 Haekal, Sejarah Hidup., 18.
} 
kehidupan setelahnya. Yahudi yang pernah dipeluk oleh salah satu penguasa daerah Yaman (Zu Nuwas) menawarkan sepuluh ajaran kebaikan dan menjadi bagian dari bangsa terbaik di dunia (Yahudi). Berdasarkan produk yang ditawarkan para pesaing dakwah khususnya paganisme terlihat bahwa kebutuhan dasar penduduk Jazirah Arab khususnya kota Makkah saat itu adalah perlindungan atau rasa aman dari ganasnya alam dan serangan suku ataupun kabilah lain.

Kesimpulan terkait kebutuhan dasar mad'uw saat itu amat penting untuk merumuskan inovasi produk demi menciptakan blue ocean. Tetapi dalam bidang dakwah, inovasi produk tentunya ada batasan yaitu sejauh inovasi produk yang dilakukan, tidak mengubah/menggeser substansi produknya atau mengubah nilai-nilai yang didakwahkan. Dalam konteks Nabi sebagai subjek dakwah, maka substansi dari produk yang disampaikan kepada pasar tetaplah harus tauhid (hanya mengillahkan Allah dan mengakui Nabi Muhammad sebagai utusanNya). Sehingga dengan batasan ini, maka inovasi bisa dilakukan dengan menawarkan manfaat tambahan jika memeluk agama Islam antara lain, pertama, semua manusia yang masuk Islam telah menjadi abdi dari penguasa seluruh alam semesta, Allah-lah penguasa alam semesta yang sesungguhnya, sehingga hanya Dialah yang pantas dimintai perlindungan atasnya. Selain itu juga ada kemanfaatan bahwa semua umat Islam adalah saudara tidak melihat suku mana atau kabilah mana, semuanya akan saling melindungi satu sama lain. Kedua, inti produk tersebut menjawab kebutuhan dasar para penduduk kota Makkah khususnya, maupun penduduk Jazirah Arab secara umum. Dengan inovasi produk secara umum ini, subjek dakwah bisa menciptakan blue ocean dalam peta persaingan dakwah saat itu sehingga mampu meraih kemenangan.

Kedua, penerapan prinsip fokus pada gambaran besar. Operasionalisasi prinsip ini adalah merumuskan rencana strategi organisasi dakwah yang memasukkan ide blue ocean yang telah dirumuskan sebelumnya. Rencana strategi dakwah tentunya berangkat dari analisis keadaan strategis dari internal subjek dakwah, pesaing dakwah dan lingkungan serta pasar dakwah. Internal subjek dakwah sendiri memiliki kekuatan strategis antara lain: (a) subjek dakwah sendiri yang dikenal sebagai Al-Amin (seseorang yang benar-benar dapat dipercaya) baik di Kota Makkah bahkan di daerah-daerah sekitar Makkah juga mendengar sosok yang Al-Amin, ini merupakan modal yang penting untuk meyakinkan pasar; (b) produk dakwah yang matang dan mapan yaitu Islam yang mampu menjawab kebutuhan dasar penduduk Makkah maupun Jazirah Arab saat itu; (c) Alquran yang memiliki seni sastra dan kandungan makna sangat dalam, sehingga mampu memikat hati orang Arab yang punya budaya seni sastra khususnya terkait sajak; (d) sumber daya manusia dalam umat Islam yang sangat militan dan rela berkorban demi suksesnya dakwah Islam. Sedangkan secara kelemahan strategis umat Islam saat itu adalah: (a) secara jumlah masih amat sedikit, dan secara pengaruh di masyarakat juga terbatas; (b) masih berada dalam tekanan fisik dan psikis yang luar biasa dari Suku Quraisy secara umum, bahkan jika terus dibiarkan akan memunahkan ajaran Islam dikarenakan gugur semua pemeluknya.

Sedangkan pesaing khususnya kaum Paganisme Quraisy memiliki aspek 
menguntungkan (peluang) antara lain: (a) di antara mereka masih ada yang bersimpati kepada Nabi Muhammad meski tidak masuk Islam. Hal ini bisa dilihat dari pengiriman perbekalan di atas seekor unta yang rutin ke celah-celah gunung dimana umat Islam berlindung di masa pemboikotan, pengiriman ini dilakukan oleh Hisyam bin $\mathrm{Amr}^{33}$ (b) masih adanya hierarki/kasta di masyarakat Arab saat itu. Misalkan antara budak dengan tuannya, antara kabilah yang terpandang di masyarakat dengan kabilah biasa; (c) produk mereka tidak menjawab kebutuhan pasar dakwah dengan sebenarbenarnya, hanya seakan-akan menjawab. Karena patung yang mereka sembah tidak benar benar menguasai alam semesta dan mereka masih terbatasi oleh kasta di masyarakat sehingga mereka tidak benarbenar bisa memenuhi kebutuhan pasar akan perlindungan dari ganasnya alam dan serangan kabilah lain. Sedangkan aspek yang mengancam dari pesaing antara lain: (a) mereka akan berbuat apapun untuk tetap melestarikan paganismenya termasuk menyiksa dan membunuh kaum muslim awal; (b) jumlah mereka cukup besar, bahkan mayoritas di kota Makkah; (c) mereka juga merupakan penguasa di kota Makkah; (d) Mereka juga tidak segan melakukan bujuk rayu terhadap subjek dakwah dan pengikutnya untuk kembali ke ajaran paganisme.

Sedangkan dari lingkungan memiliki aspek yang menguntungkan antara lain adanya musim haji di bulan-bulan suci yang menjadikan kota Makkah tujuan kafilah dagang dan orang-orang yang mau mengunjungi Kakbah. Momen ini merupakan peluang yang berpotensi untuk meluaskan pasar dakwah. Selain itu lingkungan juga memiliki potensi ancaman strategis yaitu adanya kebiasaan saling menyerang antara kabilah-kabilah jika mereka tidak terikat perjanjian damai atau menyerang rombongan dagang/musafir yang dalam perjalanan. Untuk pasar dakwah memiliki aspek potensi keuntungan strategis dari sisi kebutuhan dasar mereka akan perlindungan keamanan baik dari ganasnya alam maupun serangan kabilah lain. Sedangkan aspek potensi ancaman strategis dari pasar adalah mereka memiliki ikatan yang kuat dengan kabilah/suku mereka. Sehingga akan menjadi hal yang amat berat bagi mereka untuk berbeda keyakinan dengan keluarga besar mereka atau kabilah mereka, hanya ada sebagian kecil orang saja yang mampu melepaskan belenggu itu.

Berdasarkan analisis kondisi strategis di atas, keunggulan kompetitif subjek dakwah terhadap pesaing khususnya kaum paganisme di Makkah adalah: (a) subjek yang dikenal Al-Amin (yang dapat dipercaya); (b) produk dakwah Islam benar benar mampu menjawab kebutuhan mad'uw saat itu; (c) umat Islam (kaum muslim Makkah) sangat militan, rela berkorban apapun demi tegaknya Islam, dan mereka saling melindungi dengan kuat tanpa batasan kasta. Meski demikian tidak bisa dipungkiri ancaman yang datang dari pesaing khususnya kaum Quraisy semakin kuat dan mengancam eksistensi umat Islam. Maka menjadi penting strategi dakwah antara lain melakukan: (a) dakwah secara sembunyi-sembunyi (baik waktu maupun tempat). Aspek waktu yang dimaksud adalah mencari waktu dakwah yang dimana saat itu jarang orang lalu-lalang di jalan (biasanya

\footnotetext{
33 Ibid., 148.
} 
dan sudah dilakukan Nabi yaitu malam hari). Aspek tempat maksudnya mencari tempat dakwah (mendialogkan Islam dengan mad'uw) dalam tempat yang tersembunyi, di dalam rumah, goa, atau yang lainnya; (b) mulai mencari pasar di luar kota Makkah, yang mungkin bisa sekaligus menjadi tempat kehidupan baru kaum muslimin saat itu. Strategi kedua ini juga dilakukan oleh Nabi sebagai subjek dakwah dengan melakukan dakwah kepada kabilah-kabilah yang bermukim di sekitaran luar kota Makkah (Thaif, dan lainnya) serta mendakwahkan Islam pada kabilah atau rombongan yang datang ke kota Makkah di bulan-bulan suci. Dalam strategi kedua tersebut ditawarkan produk dakwah yang inovatif (Islam mampu melindungi tanpa ada batasan sekat kasta). Hal tersebut untuk memastikan ide blue ocean strategy dalam konteks dakwah Nabi menjelang Hijrah ini akan bisa berjalan karena selaras dengan strategi dakwah yang dirumuskan.

Ketiga, salah satu keluaran dari prinsip kedua baik keunggulan kompetitif aspek produk dan strategi kedua, beririsan dengan penerapan dari prinsip ketiga yaitu menjangkau melampaui permintaan yang ada. Sedangkan operasionalisasi prinsip ketiga blue ocean strategy adalah subjek perlu meningkatkan kapasitas/keluasan pasar dakwah dengan melakukan inovasi produk dakwah yang berbeda dari sebelumnya dengan berbasis pada apa yang dihargai oleh pasar dakwah secara umum. Pada konteks Nabi saat menjelang peristiwa hijrah ini, kedua prinsip (kedua dan ketiga) beririsan atau dilakukan secara bersamaan diakibatkan faktor strategis lingkungan kota Makkah yang menjadi tempat tujuan dagang dan tujuan ritual haji (pra Islam) di bulanbulan suci, dan juga faktor tekanan yang luar biasa dari kaum Quraisy Makkah kepada umat Islam. Di saat faktor ancaman yang luar biasa besar datang, di saat yang sama pula terdapat faktor strategis kota Makkah yang memungkinkan kabilah-kabilah luar kota Makkah datang mengunjungi kota Makkah. Kedua faktor inilah yang menjadikan keluaran prinsip kedua juga sekaligus menjalankan prinsip ketiga, yaitu mendakwahkan Islam bukan hanya kepada pasar dakwah selama ini tetapi juga kepada nonkonsumen, dalam hal ini kabilah lain yang datang ke kota Makkah ataupun bermukim di luar kota Makkah. Tentunya dengan adanya tuntutan demikian, maka produk yang ditawarkan juga harus sesuai dengan pasar dakwah yang umum tersebut (dan itu juga masuk dalam keluaran pada prinsip kedua). Kedua hal tersebut juga dilakukan Nabi sebagai subjek dakwah saat itu dengan Nabi mendatangi langsung kabilah tersebut dan yang kedua adalah menunggu musim haji, dengan begitu akan banyak kabilah-kabilah dari luar Makkah melakukan ziarah ke Makkah. Di sanalah tempat Nabi menemukan banyak pasar baru yang berpotensi masuk Islam. Meski banyak menerima penolakan dari kabilah-kabilah di luar kota Makkah, Nabi Muhamamad tidak pernah mengeluh ataupun menyerah, beliau terus dengan sabar mencari lagi kabilah, sekelompok orang ataupun seorang individu yang ditemui untuk diajak berdialog mengenai Islam.

Akhirnya menemukan pasar yang benarbenar sesuai sehingga bisa menerima produk Islam yang beliau tawarkan/dakwahkan, yaitu saat Nabi sebagai subjek dakwah melakukan dakwah/pemasaran pada kabilah dari Khazraj (6 orang). Nabi memahami adanya kebutuhan suku Aus dan Khazraj dari Madinah akan kedamaian dan perlindungan 
dari potensi bahaya yang mengancam dari Yahudi, maka subjek perlu memberikan penawaran produk alternatif (Islam) yang menjawab kebutuhan kedua suku tersebut. Sehingga kebutuhan mereka adalah rasa aman, mereka ingin peperangan itu segera berakhir tidak ada lagi permusuhan antara Aus dan Khazraj. Dan mereka butuh jaminan rasa aman dari apa yang dibicarakan oleh orang Yahudi. Dimana ketika ada Nabi datang, Nabi bersama orang-orang Yahudi akan menghabisi mereka. Serta mereka juga butuh pemimpin yang baik yang dapat menjadikan kedua kubu (Aus dan Khazraj) berdamai.

\section{Prinsip-Prinsip Blue Ocean Strategy} dalam Proses Dakwah Pertama Kali kepada Orang-Orang Yastrib sampai Hijrahnya Nabi Masuk Islamnya keenam orang Khazraj dari Yastrib yang bertemu Nabi di antara Aqabah dan Mina merupakan pangkal dari perkembangan Islam di Yastrib. Lalu merekapun kembali ke Madinah. Saat Nabi telah selesai melakukan Isra Mikraj. Saat turun wahyu Al-Israa ayat 16-17, di dalam surat itu seakan Allah telah memberikan tanda bahwa Rasulullah akan memperoleh tempat perlindungan yang aman bagi Islam sekaligus sebagai pusat penyebaran dakwah ke seluruh dunia. ${ }^{34}$ Pada musim haji berikutnya, datang dua belas orang dari Yatsrib menemui Nabi. Lima orang di antara mereka adalah orang yang tahun lalu bertemu dengan Rasulullah. Sedangkan tujuh orang sisanya adalah orang yang baru memeluk Islam. Mereka semua datang menemui Rasul di Aqabah di Mina. Mereka menyatakan baiatnya. Isi dari baiatnya adalah berjanji untuk tidak menyekutukan

34 Ibid., 183.

35 lbid., 186.
Allah dengan suatu apapun, tidak mencuri, tidak berzina, tidak membunuh anak-anak mereka sendiri, tidak akan berbuat dusta yang diada-adakan di antara tangan dan kaki, tidak durhaka kepada Rasul atas segala perintah beliau yang baik, dan barang siapa ketika melakukannya, maka la akan mendapatkan surga dan ketika melanggarnya maka akan masuk neraka. ${ }^{35}$

Kemudian setelah Baiat itu, Nabi juga menyuruh utusannya Musaib bin Umair untuk ikut bersama orang-orang yang sudah berbaiat itu ke Yastrib, dimana tugasnya adalah menyebarkan agama Islam di sana. Tak disangka pekembangan Islam sangat pesat di Yastrib ditambah lagi Sa'ad bin Mu'adz dan Usain bin Hudhair para pemuka Bani Abdul Asyhal yang masuk Islam, padahal awalnya mereka sangat memusuhi Islam. Setelah mereka dibacakan ayat Alquran dan diberi tahu lebih dalam tentang Islam, mereka langsung masuk Islam. Dan karena mereka pemimpin, maka masyarakatnya pun masuk Islam semua. Sehingga jumlah Islam lantas menjadi banyak dan semakin besar. ${ }^{36}$ Ada data yang menunjukkan bahwa Nabi Muhammad saw. menginginkan orang-orang muslim untuk melindungi diri dan berhijrah ke Madinah, sedangkan Nabi sendiri masih menunggu perintah dan izin Allah untuk melakukan hijrah ke Madinah. Kemudian barulah keluar perintah Allah untuk menyuruh Nabi Muhammad berhijrah, kemudian Nabi mendatangi Abu bakar dan mengajak Abu bakar untuk menjadi teman hijrah Nabi ke Madinah. Sebelum Nabi pergi dari rumahnya, Nabi menyuruh Ali untuk mengembalikan barang-barang yang telah dititipkan kepada beliau, sehingga Rasul

${ }^{36}$ Al-Mubarakfury, Shahih Sirah., 184. 
menyuruh Ali untuk tetap tinggal di Makkah dan di rumah Rasul ${ }^{37}$.

Saat Nabi berdakwah kepada orang Aus dan Khazraj dari Madinah sebenarnya ada beberapa penawaran yang diberikan $\mathrm{Nabi}$ kepada mereka antara lain: ${ }^{38}$ (a) perdamaian antara kaum Aus dan Khazraj; (b) produk spiritual ketuhanan monoteisme; (c) kepemimpinan; (d) ikrar Aqabah pertama; (e) memberikan hubungan yang lebih dari sekadar persaudaraan melalui ikrar Aqabah kedua. Dalam ikrar Aqabah kedua mereka berikrar untuk saling membela di antara Nabi dan mereka seperti mereka membela anak dan istri mereka, dan beberapa ikrar lain serta Nabi mengangkat 12 pemimpin yang akan memimpin umat muslim di Madinah di bawah kepemimpinan beliau. ${ }^{39}$

Ketika mereka mendengar bahwa Rasul sudah berhasil keluar dari Makkah, maka yang mereka lakukan adalah berjalan ke luar kampung sehabis salat subuh dan menunggu kedatangan Nabi. Mereka setia menunggu kedatangan Nabi hingga tidak beranjak dari tempat mereka. Hingga matahari mulai menyengat tubuh mereka, mereka mencari tempat berteduh sambil tetap menunggu Nabi. Sampai kemudian ada yang melihat Nabi dan berteriak bahwa orang yang mereka tunggu sudah datang dan sontak membuat mereka berkerumun dan ingin melihat Nabi. Nabi disambut dengan hormat sesampainya di Madinah. Semua rumah dan jalan ramai bergema tahmid dan tasbih. Hingga kebetulan Nabi berhenti di depan bani Najjr, yang tidak lain masih saudara nabi. Mereka merasa terhormat sekali ketika Nabi mau datang untuk mampir. ${ }^{40}$

37 Ibnu Hisyam, Sirah Nabawiyah Ibnu HiSyam, (Jakarta: Darul Falah,2000), 423

38 Haekal, Sejarah Hidup., 171.
Proses dakwah pada masyarakat kota Yatsrib di atas hingga hijrahnya Nabi ke Yatsrib/Madinah, merupakan wujud dari prinsip keempat dari blue ocean strategy yaitu menjalankan rangkaian strategis secara benar. Operasionalisasi dari prinsip ini pada bidang dakwah adalah subjek dakwah perlu merumuskan langkah implementasi yang strategis bagi ide samudra birunya sehingga bisa terwujud dengan baik. Langkah implementasi yang strategis ini antara lain memastikan adanya utilitas yang istimewa dari produk dakwah subjek untuk pasar dakwahnya (mad'uw), kemudian meminimalkan bentuk pengorbanan yang diberikan mad'uw pada saat membeli/menerima dan meyakini produk dakwah, serta meminimalisir biaya material ataupun nonmaterial yang dikeluarkan oleh subjek dakwah dalam memproses, menciptakan, dan menghantarkan produk dakwahnya, serta memastikan mampu mengatasi rintangan yang menghadang. Awal penerapan prinsip ini dimulai dari melakukan pengecekan apakah inovasi produk yang sudah dirumuskan bisa menghasilkan nilai utilitas yang istimewa pada pasar dakwah yang ditarget pada prinsip ketiga. Dengan kebutuhan dasar akan perlindungan dari ancaman Yahudi dan peperangan besar antara Aus dan Khazraj, maka produk Islam yang menawarkan perlindungan tanpa batasan sekat kasta suku menjadi sangat menjawab kebutuhan tersebut. Hal ini dikarenakan dengan meleburnya mereka dalam Islam (pengakuan akan keilahan Allah SWT. dan kerasulan Muhammad saw.) maka di antara suku Khazraj dan Aus hanya ada satu ikatan

\footnotetext{
39 Hisyam, Sirah Nabawiyah., 398.

40 Al-Mubarakfury, Shahih Sirah., 217.
} 
yang mempersatukan mereka yaitu Islam. Dengan Islam mereka bisa terhindar dari bencana kehancuran akibat perang besar di antara mereka dan sekaligus mereka akan saling bekerjasama baik antara mereka ataupun dengan umat Islam dari kota Makkah untuk menghadapi ancaman yang datang dari Yahudi. Keistimemawaan ini perlu diwujudkan dalam satu ikatan yang masuk dalam relung kultur masyarakat Arab saat itu, yaitu sumpah setia. Dengan adanya baiat atau sumpah kesetiaan untuk menjalankan apa yang menjadi isi sumpah, maka orang Arab dengan kultur mereka saat itu akan berjuang habis-habisan/secara militan akan terus menjalankan sumpah tersebut (bai'atul Aqobah satu dan dua). Pada titik inilah harga/biaya yang diberikan oleh Suku Khazraj dan Aus dengan melakukan sumpah dan masuk Islam, mereka menyerahkan diri mereka untuk bersedia diatur oleh Nabi, tetapi utilitas yang mereka terima adalah hal istimewa serta bertemu dengan biaya yang dikeluarkan oleh subjek juga minimal sekali. Selain mencari tempat yang tersembunyi untuk baiat, juga mengirimkan satu utusan ke Medinah untuk mendakwahkan Islam guna mendampingi umat Islam di Madinah.

Pada tahap ini akan sempurna strategi ini bila subjek dakwah (Nabi) bisa keluar dari Makkah yang penuh ancaman, menuju dan bermukim ke Madinah guna mendakwahkan Islam ke pasar yang lebih luas. Hal ini bukan berarti tidak akan ada rintangan, potensi rintangan berjalannya strategi ini antara lain munculnya provokasi saat rombongan perwakilan pulang ke Kota Madinah, sehingga mereka murtad kembali atau setidaknya Suku Aus dan Khazraj di Madinah sulit menerima Islam, dibunuhnya Nabi oleh suku Quraisy, di bunuh semua orang Islam di
Makkah. Maka untuk memastikan rintangan bisa diatasi, perlu direncanakan langkah: (a) mengirim utusan untuk mendampingi umat Islam di Madinah, karena sebagai Nabi yang memiliki perintah berdakwah yang awalnya di Makkah, maka Nabi tentunya tidak akan bisa sekehendak hati memindahkan lahan dakwahnya. Ini juga yang membuat berbeda dengan bidang bisnis, dalam konteks tersebut Nabi perlu menunggu perintah dari Allah terkait pemindahan lokasi dakwah; (2) jika sudah ada perintah, maka perlu merencanakan bagaimana taktik pindahnya/hijrahnya Nabi sehingga tidak ditangkap oleh kaum Quraisy Makkah. Nabi mengeksekusi perintah hijrah dengan sangat baik dan lihai sehingga bisa sukses sampai di Madinah dengan selamat; (c) dalam rangka mengantisipasi pembunuhan umat Islam Makkah seluruhnya oleh Quraisy, maka perlu dilakukan perpindahan permukiman mereka dari Makkah ke Madinah tetapi secara bertahap (dalam rombonganrombongan kecil). Dengan demikian akan bisa selamat dari ancaman suku Quraisy.

\section{Kesimpulan}

Penerapan prinsip-prinsip blue ocean strategy pada dakwah Nabi dalam peristiwa Hijrah ke Madinah dan yang mengitarinya, memiliki latar belakang sebagaimana dalam situasi persaingan red ocean. Nabi (subjek dakwah) saat di Makkah sebelum Hijrah menghadapi kompetitor yang amat kuat dan dominan yaitu elit atau pimpinan suku Quraisy. Pascakematian paman dan istri beliau, tekanan dari Quraisy Makkah semakin kuat baik itu berupa tekanan fisik dan psikis hingga nyawa, keadaan inilah yang merupakan wujud kongkret red ocean. Keadaan ini yang menjadi konteks dari penerapan empat prinsip blue ocean 
strategy. Dalam analisis penerapan teori pada prinsip pertama bisa disimpulkan bahwa penerapan prinsip pertama blue ocean strategy dalam bidang dakwah sangat penting dilakukan pembatasan. Batasan ini menjadi sangat penting terutama dalam melakukan inovasi produk. Inovasi produk dalam dunia dakwah mesti dibatasi oleh nilai-nilai dalam dakwah atau ajaran Islam. Sehingga tidak bisa seorang subjek dakwah melakukan inovasi produk dakwah tanpa batasan, hanya karena ingin memenangkan persaingan dakwah.

Penerapan prinsip kedua blue ocean strategy dalam dakwah bisa sekaligus penerapan prinsip ketiga yaitu subjek dakwah memiliki keunggulan kompetitif yaitu: (a) subjek yang dikenal Al-Amin (yang dapat dipercaya); (b) produk dakwah Islam benar benar mampu menjawab kebutuhan mad'uw saat itu. (c) Umat Islam (sdm muslim) sangat militan, rela berkorban apapun demi tegaknya Islam, dan mereka saling melindungi dengan kuat tanpa batasan kasta. Dan juga dirumuskannya strategi dakwah antara lain: (a) dakwah secara sembunyi-sembunyi (baik waktu maupun tempat); (b) mulai mencari pasar di luar kota Makkah, yang mungkin bisa sekaligus menjadi tempat kehidupan baru kaum muslimin saat itu. Keunggulan kompetitif kedua dan strategi dakwah kedua merupakan sekaligus penerapan prinsip ketiga. Penerapan prinsip keempat yang terkait dengan menjalankan rangkaian strategis yang benar ini seputar implementasi strategi yang telah dirumuskan dengan dipastikan adanya utilitas yang istimewa bagi mad'uw (dalam hal ini suku Aus dan Khazraj) yang dengan adanya sumpah/baiat yang dilakukan maka terjadilah persaudaraan di antara mereka dan sumpah saling melindungi layaknya keluarga di baiat Aqabah kedua merupakan harga minimal tetapi mendapatkan utilitas yang istimewa bagi mereka. Serta dengan memastikan tiga rintangan yang berpotensi menghalangi berjalannya strategi tersebut bisa dipecahkan.

Rekomendasi yang diberikan sebagai hasil dari studi ini adalah, pertama, dalam penerapan prinsip pertama blue ocean strategy pada bidang dakwah penting disadari oleh subjek dakwah adanya batasan inovasi yang bisa dilakukan subjek dakwah. Nilai-nilai ajaran yang didakwahkan subjek dakwah sekaligus menjadi batasan dari inovasi produk dakwah yang dilakukan. Dalam hal ini bisa dimaknai bahwa inovasi yang dilakukan subjek dakwah tidak boleh melanggar nilai-nilai dari yang didakwahkan. Kedua, dalam bidang dakwah penerapan prinsip kedua dan ketiga dari blue ocean strategy memungkinkan dijadikan satu. Maksud dari pernyataan ini adalah ternyata dalam dunia dakwah suatu keunggulan kompetitif suatu subjek dakwah bisa sekaligus menjadi capaian subjek dakwah dalam melampaui permintaan dari pasar dakwahnya. Hal ini dapat terjadi dikarenakan subjek dakwah dalam merumuskan keunggulan kompetitifnya berbasiskan pada analisis kondisi pasar dakwahnya, khususnya kebutuhan dan permintaan pasar dakwahnya; selain analisis keadaan pesaing dan kondisi internal dari subjek dakwah sendiri. 


\section{Bibliografi}

Al-Mubarakfury, Snafiyyurrahman. Shahih Sirah Nabawiyah. Bandung: Jabal, 2012.

Creswell, John W. Research Design. Yogyakarta: Pustaka Pelajar, 2016.

David, Fred R. Manajemen Strategis Konsep. Jakarta: Salemba Empat, 2009.

Haekal, Muhammad Husain. Sejarah Hidup Muhammad. Bogor: Litera AntarNusa, 2006.

Hisyam, Ibnu. Sirah Nabawiyah Ibnu Hisyam. Jakarta: Darul Falah, 2000.

Kim, Chan, dan Renee Mauborgne. Blue Ocean Strategy. Jakarta: PT Serambi Ilmu Semesta, 2005.

Kim, W. Chan, dan Renee Mauborgne. Blue Ocean Shift Pergeseran Samudra Biru Melampaui Persaingan (Jakarta:PT Gramedia Pustaka Utama, 2017.

Kotler, Philip, dan Gary Armstrong. Prinsip-prinsip Pemasaran Jilid 1. Jakarta: Penerbit Erlangga, 2008.

Miles, Matthew B, dan A. Michael Huberman. Analisis Data Kualitatif. Diterjemahkan oleh Tjejep Rohendi Rohidi. Jakata: UI Press, 1992.

Moleong, Lexy J. Metodologi Penelitian kualitatif. Bandung: PT Remaja Rosdakarya Bandung, 2015.

Munir, M, dan Wahyu Ilaihi. Manajemen Dakwah. Jakarta: Rahmat Semesta, 2006.

Zed, Mestika. Metode Penelitian Kepustakaan. Jakarta: Yayasan Obor Indonesia, 2004. 